Annals of Warsaw University of Life Sciences - SGGW

Land Reclamation No 50 (1), 2018: 3-17

(Ann. Warsaw Univ. of Life Sci. - SGGW, Land Reclam. 50 (1), 2018)

\title{
Water quality in forests small retention reservoirs in southern Poland - case study
}

\author{
MIROSŁAW WIATKOWSKI ${ }^{1}$, CZESEAWA ROSIK-DULEWSKA $^{2}$, \\ DARIA NIKEL ${ }^{2}$, URSZULA KARWACZYŃSKA ${ }^{2}$ \\ ${ }^{1}$ Faculty of Environmental Engineering and Geodesy, Wrocław University of Environmental and Life \\ Sciences \\ ${ }^{2}$ Faculty of Natural Sciences and Technology, University of Opole
}

\begin{abstract}
Water quality in forest small retention reservoirs in southern Poland - case study. This paper provides an analysis of water quality in three newly constructed small water retention reservoirs (Rudziczka, Niemysłowice I and Paciorkowy) located in forested areas of the forest district Prudnik in the Opolskie Province (southern Poland). The main purpose of these reservoirs is not only water retention, but also flood safety, fire protection, recreation and ecology. This paper presents the results of research carried out in December 2014 and May 2015. The assessment of water quality was performed in accordance with the applicable provisions on water quality assessment. Moreover, an assessment of eutrophication of water and of the usability of water in reservoirs is given (an analysis of suitability of water as a fish habitat). The research shows that the investigated waters are of quality class I in terms of the values of electrolytic conductivity, nitrates, nitrites, dissolved oxygen $\mathrm{COD}_{\mathrm{Mn}}$, calcium, magnesium and general hardness. In terms of the temperature (the Rudziczka reservoir), and the content of ammonia and phosphates they were of quality class II. The reaction, $\mathrm{BOD}_{5}$ and sulphates and chlorides content exceeded the threshold values for class II. It was also found that the investigated waters are not eutrophic. Based on the indicators such as reaction, dissolved oxygen, ammonia nitrogen and temperature, the waters in all the reservoirs except for Rudziczka met the quality requirements for habitats of salmonids and cyprinids. The living conditions for fish are deteriorated most by the increased levels of $\mathrm{BOD}_{5}$ and of nitrites in the Rudziczka and Paciorkowy reservoirs. The analysis of seasonal fluctuation in concentrations of water quality indicators in the investigated water
\end{abstract}

bodies showed that in winter the concentrations of indicators were higher for nitrates, phosphates, electrolytic conductivity, calcium and general hardness and lower for temperature, reaction, nitrites, ammonia and dissolved oxygen. While the water in the Paciorkowy reservoir had the worst quality, the surface water in the Rudziczka reservoir had the best quality. The research initiated in small forests water retention reservoirs provides preliminary information on water quality and the importance of investigated reservoirs for increased retention.

Key words: small water reservoirs, forest catchments, water quality, water usability, forest district Prudnik

\section{INTRODUCTION}

Sustainable development of multifunctional forest management should be based on small water retention infrastructure, which is supposed to accumulate water suitable for direct, economic use. Other factors to be taken into account should include increasing the humidity of habitats by raising the ground water level according to the habitat type of forest, the changes of microclimate able to mitigate the consequences of weather changes, increasing the biodiversity in homogeneous complexes as well as reducing the processes of erosion 
(Mioduszewski 2008, 2016, Stasik et al. 2011). In order to limit the runoff from river catchments it is necessary to create systems that allow closing the circulation of water in the catchment or its sections (the so called retention). This can be done through natural processes that occur in the environment or by actions undertaken by humans (Liberacki et al. 2008, Ostrowski 2011). Technical structures of small retention help in providing water to animals and birds, they may be a landscape asset and may be used for fire or flood protection (Ciepielowski 2001, 2004, Tyszka 2009, Mioduszewski 2016, Wiatkowski 2016). An increase of water resources in forests and wetland habitats and slowing down of the surface runoff is essential for the development of forests (Pierzgalski 2008, Tyszka 2009, Janusz et al. 2011). This is also confirmed by Frydel (2006), who claims that forested areas are an important element, the existence of which is conditioned by the amount of water: both its excess and shortage have a negative impact on the forest complexes. Deficiency of water significantly increases the fire risk and excess of water makes the trees die (Frydel 2006). Specialists call for regeneration of old and creation of new small retention reservoirs. Water reservoirs should be located in natural topographic lows in a way that interferes the least in the natural landscape (Mioduszewski 2008). As pointed out by specialists, the forest ecosystem has a big retention capacity and can, in particular, shape the so called small retention that results from the longer time and path of water circulation and intensified self-cleaning processes (Mioduszewski 2004, 2016, Miler 2009, 2015, Mosiej and Bus 2015). Small wa- ter reservoirs are structures highly susceptible to external influences (Szczykowska et al. 2017). Therefore, location in a given type of catchment has a number of consequences related to their functioning and reaching a given ecological state. This state is best described by an assessment of water quality Liberacki and Szafrański (2008), nature and transformation of vegetation and by observation of external symptoms of degradation of reservoirs (Skwierawski 2010). Doubtlessly, any form of water retention in small reservoirs is an achievement of forest services (Tyszka 2004). In parallel with the problem of availability of water, there is also the problem of its appropriate quality, which is fundamental for its usage for planned objectives. Testing of water quality in small retention reservoirs on forested areas is currently not too frequent, but it is commonly known that forests stabilize the chemistry of surface waters (Małek and Gawęda 2006). The following small retention reservoirs in the forest district of Prudnik have been selected for water quality testing: the Rudziczka reservoir, the Niemysłowice reservoir I and the Paciorkowy reservoir. Since the research related to water quality in small reservoirs presented to date in the literature focuses on agricultural and urban reservoirs, the preliminary results on water quality given in this paper are significant.

The goal of this paper is to present results of research on the quality of water in three small retention reservoirs located in the forest district of Prudnik in the Opolskie Province. The work was carried out based on the physical and chemical parameters measured in two measurement sessions in December 2014 
and May 2015. The paper also points out the importance of the investigated reservoirs in terms of creating conditions for increased retention and water quality management.

\section{CHARACTERISATION OF THE RESEARCH AREA}

The Opolskie Province is a part of the administrative structure of the Regional State Forest Directorate in Katowice. It is one of seventeen regional directorates in Poland and one of the biggest in the country. Commercial forestry takes place directly in 38 forest districts. The forest district of Prudnik is located in the Opolskie province, on the area of 16 communes, including that of Prudnik. Its yearly average temperature of air is $8.3^{\circ} \mathrm{C}$. The long-term average precipitation is about $740 \mathrm{~mm}$. The forest district of Prudnik is located in the Odra river basin area. Its central part is located in the Osobłoga river basin area. Its main left-bank tributaries are the rivers Biała and Prudnik (Nadleśnictwo Prudnik 2010a, 2014).

The research was carried out in three small retention reservoirs located in the commune of Prudnik: the Rudziczka reservoir, the Niemysłowice reservoir I and one of the five chain reservoirs (the $\mathrm{Pa}$ ciorkowy reservoir) - Figure 1 . The reservoirs were built under the project entitled "Preventing the consequences of precipitation water runoff in mountain areas. Increasing the retention and maintaining the streams and related infrastructure in good condition", which was carried out under the third priority axis "water retention and ensuring flood safety".
The first research object is the Rudziczka reservoir. This small water retention reservoir is located deep in the forest in the Prudnik commune, in the village of Rudziczka (Fig. 1). Its surface area is 0.5 ha. Its main role is (a) retention of water from the Orzechówka stream and (b) flood protection - flattening out of the flood wave and fire protection for the Rudziczka mid-field forest complex. Documents show that this reservoir is not intended for fish cultivation. The water is discharged by means of an outlet box (monk) to a forest ditch and then to the Orzechówka stream. The reservoir dimensions are as follows: length $72 \mathrm{~m}$, average reservoir width $-69 \mathrm{~m}$, average reservoir depth $-0.85 \mathrm{~m}$, average reservoir capacity - approx. $4,200 \mathrm{~m}^{3}$, total reservoir capacity $6,000 \mathrm{~m}^{3}$ (Nadleśnictwo Prudnik 2010b). Water samples in this reservoir were taken at three measurement points. Point St.R1 was located on the Orzechówka stream which feeds the reservoir, at the inlet of feeding pipeline, at $\mathrm{km} \mathrm{2+946} \mathrm{of}$ the watercourse. Point St.R2 was located in the bowl of the reservoir (above the outflow pipeline). Point St.R3, in turn, was located at the outflow from the Rudziczka reservoir, below the outflow pipeline outlet.

The second research object was the Niemysłowice reservoir I, located in the Dębowiec forest region, Prudnik commune (Fig. 1). The Niemysłowice reservoir is located in a forest area and was reconstructed in 2011. It neighbours arable land and fish ponds, but has no impact on them. However, it does have an influence on the Prudnik river. The flooding surface of the Niemysłowice reservoir I is approx. 1.06 ha. Its total 


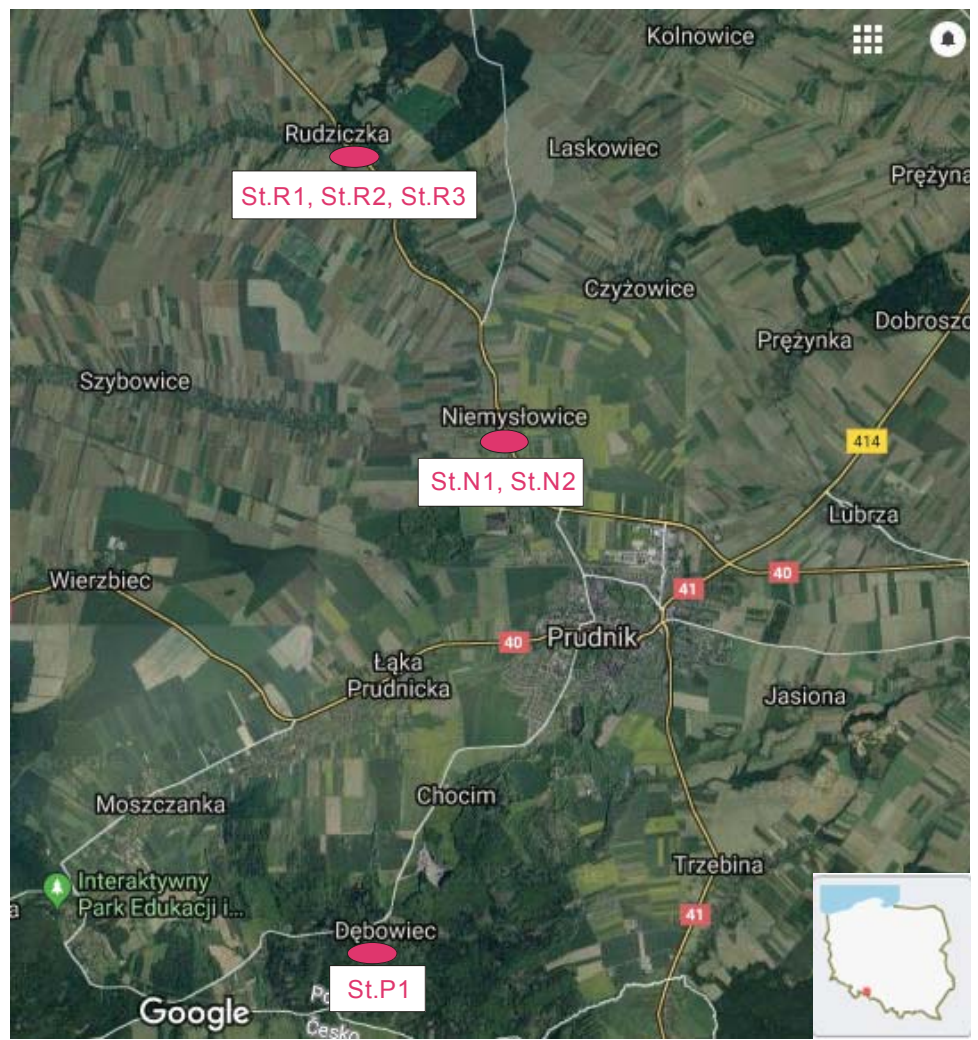

FIGURE 1. Location of the small water retention reservoirs in the forest district of Prudnik and the measuring points: the Paciorkowy reservoir (St.P1), the Niemysłowice I reservoir (St.N1, St.N2), the Rudziczka reservoir (St.R1, St.R2, St.R3)

Source: Own elaboration on the basis of https:/www.google.com/maps/@50.3414304,17.4908984,14887m/ data $=! 3 \mathrm{~m} 1 ! 1 \mathrm{e} 3 ? \mathrm{hl}=\mathrm{en}$.

surface area is 1.45 ha. The usable capacity is $9,557 \mathrm{~m}^{3}$. The average depth is $0.85 \mathrm{~m}$ (Nadleśnictwo Prudnik 2010b). The Niemysłowice reservoir I is fed by a ditch, which originates from the arable land surrounding the forest complex. Water is evacuated by means of an outlet box (monk), through the outflow pipeline to the river Prudnik. In the middle of the retention reservoir there is an island for birds. Before the reconstruction, in 1930s, the reservoir and the surrounding forested area was used as a recreational park for the residents of Prudnik.
The reconstruction work was aimed to retain surface water from the surrounding terrain in order to increase the water resources in the catchment, to manage the water system of the adjacent forest complex and to use it when needed, e.g. to put out a fire, as well as to improve the overall ecological conditions. Before the reconstruction, surface waters were making the terrain surrounding the reservoir boggy because there was no outflow from the reservoir (Nadleśnictwo Prudnik 2010b). For the purpose of quality testing, water from the Niemysłowice 
reservoir I was sampled at two measurement points. Point 1 St.N1 was located in the bowl of the reservoir (above the outflow pipeline). Point St.N2, in turn, was located on the river Prudnik, approx. $20 \mathrm{~m}$ below the outflow pipeline outlet from the reservoir (Nikel 2015).

The third research object is the $\mathrm{Pa}$ ciorkowy reservoir IV (Fig. 1). It is one of the five chain reservoirs which form a connected water retention system. The measurements were carried out at the measurement point St.P1, located in the bowl of the reservoir, $5 \mathrm{~m}$ above the outflow pipeline leading to reservoir $\mathrm{V}$. The Paciorkowe reservoirs are chain reservoirs located in the forest region of Dębowiec. Reservoirs I, II and III were constructed in the 1960s and reconstructed in 2013. Reservoirs IV and V were built in 2013. These water bodies are supplied by a shallow watercourse which flows into the Prudnik river. The reservoirs are mainly filled with precipitation and thaw waters. The overall surface area of all the five reservoirs is 0.9271 ha and the useful volume is $7,047 \mathrm{~m}^{3}$. The system of chain reservoirs consists of fire reservoirs, fire outlet boxes, through which water is directed and fire emergency weirs. There is an island for birds on the reservoir $\mathrm{V}$. The main task of these reservoirs is to retain water and ameliorate the water conditions in the area. Another function is to provide flood protection of the areas located downstream. Because of the location in the vicinity of the city of Prudnik, the place is frequently visited by locals due to its natural, cultural and landscape assets. The reservoirs are also important ecologically as a bird habitat (Nadleśnictwo Prudnik 2010).

\section{RESEARCH METHODS}

The measurements of water quality in the three reservoirs were carried out at six measurement points, in December 2014 and May 2015. Field measurements consisted of in situ testing of the reaction, temperature and electrolytic conductivity of water. Other parameters of water quality were determined in the laboratory of the Department of Land Protection at the University of Opole. The determined parameters were as follows: sulphates, nitrite nitrogen, nitrate nitrogen, ammonia nitrogen, orthophosphates, general hardness, calcium hardness and magnesium hardness, chlorides, chemical oxygen demand $\left(\mathrm{COD}_{\mathrm{Mn}}\right)$. Moreover, the levels of dissolved oxygen and of the fire day biochemical oxygen demand $\mathrm{BOD}_{5}$ (only in 2014) were determined (Nikel 2015). The points at which water samples were taken and field measurements were carried out were located in villages: for the Rudziczka reservoir - the village of Rudziczka, for the Niemysłowice reservoir I - the village of Niemysłowice, for the Paciorkowy reservoir - the village of Prudnik (Fig. 1). The Rudziczka reservoir is located in the Trzebina forest region, the two others (Niemysłowice and Paciorkowy) in the Dębowiec forest region. In all these research locations water was sampled from the subsurface layer.

The quality of water in the watercourses feeding the reservoir was assessed based on the physicochemical elements, according to the Minister of Environment Regulation from 2014 on the method of classification of water bodies, which is currently in force. An assessment of the extent of eutrophication of investigated water bodies was based on the Minister 
of Environment Regulation from 23 December 2002. The usability of water was determined by comparing the investigated indicators with the threshold values for water suitable for fish habitat (Minister of Environment Regulation from 4 October 2002).
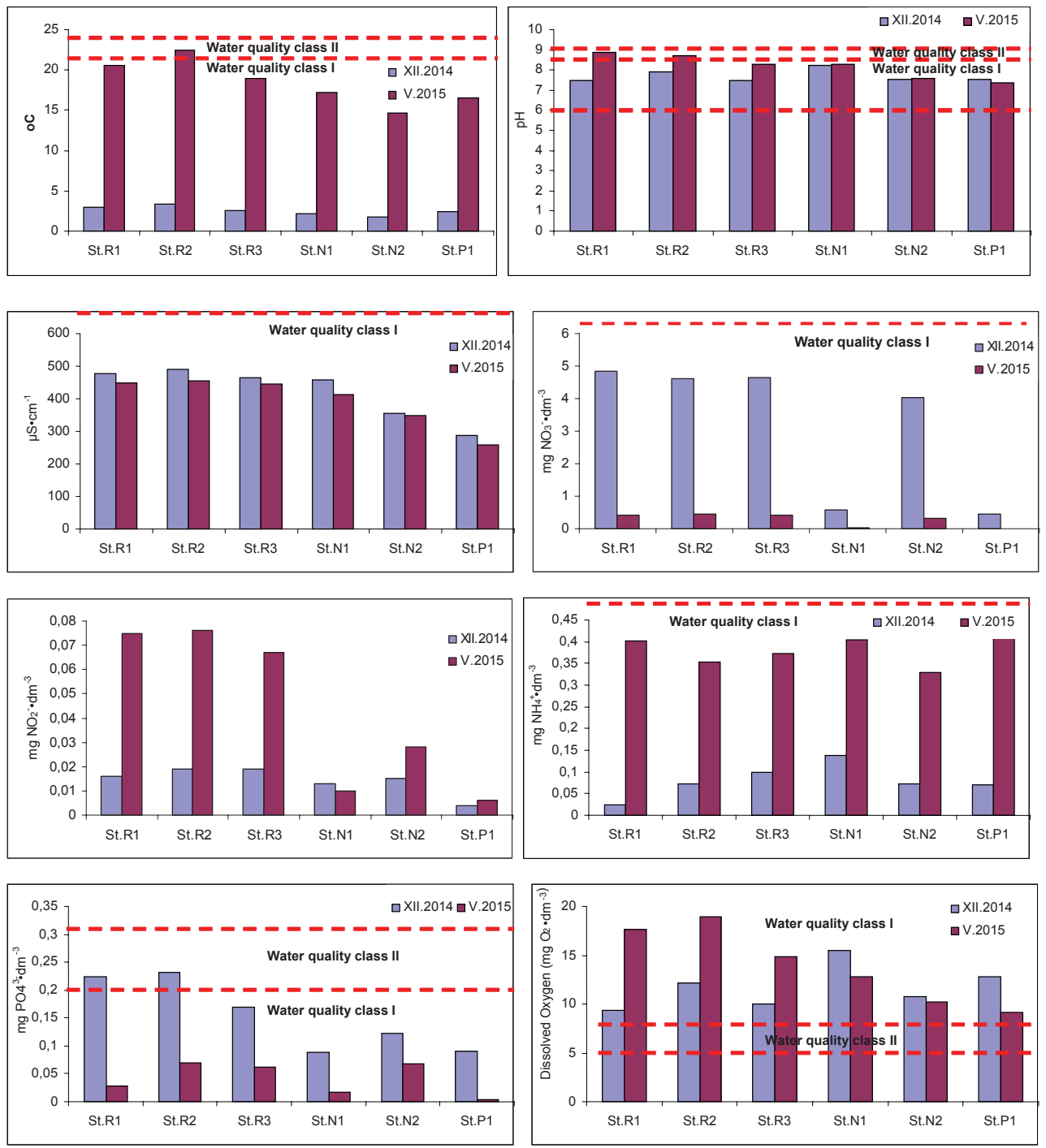

FIGURE 2. The values of water quality indicators from the three small retention reservoirs in the forest district of Prudnik, in December 2014 and May 2015 with water classes according to the Minister of Environment Regulation from 2014

Source: Own elaboration. 
reservoir St.P1) along with water classes from the Minister of Environment Regulation from 2014.

During the research period, the temperature of water in the investigated small retention reservoirs ranged from $1.8^{\circ} \mathrm{C}$ (December 2014, point St.N2 at the outflow from the Niemysłowice reservoir I) to $22.5^{\circ} \mathrm{C}$ (May 2015, point St.R2 in the Rudziczka reservoir) - Figure 2. An analysis of the water quality results over the investigated period shows that the temperature qualifies all of the investigated waters to water quality class I; the only exception is the reaction of water in the Rudziczka reservoir in May 2015 (water quality class II) (Minister of Environment Regulation from 2014).

The values of $\mathrm{pH}$ of water from the research area are given in Figure 2. Values of the investigated water samples $\mathrm{pH}$ range from 7.35 to 8.87 , thus the limits for water quality class II for water bodies are exceeded (Minister of Environment Regulation from 2014).

During the research period, the electrolytic conductivity of investigated water ranged from 259 (May 2015, point St.P1, the Paciorkowy reservoir) to $490 \mu \mathrm{S} \cdot \mathrm{cm}^{-1}$ (December 2014, point St.R2, the Rudziczka reservoir)-Figure2. The maximum values of this indicator qualify the investigated waters as water quality class I.

The concentration of nitrates over the investigated period of time ranged from $0.007 \mathrm{mg} \mathrm{NO}_{3}{ }^{-} \cdot \mathrm{dm}^{-3}$ (May 2015 , point St.P1, the Paciorkowy reservoir) to $4.85 \mathrm{mg} \mathrm{NO}{ }^{-} \cdot \mathrm{dm}^{-3}$ (December 2014, point St.R1, inflow to the Rudziczka reservoir). The values of this indicator on all of the measurement points qualify the investigated waters as water quality class I.
The concentrationa of nitrites in small retention structures ranged from $0.004 \mathrm{mg} \mathrm{NO}{ }_{2}^{-} \cdot \mathrm{dm}^{-3}$ (December 2014, point $\mathrm{P} 1$, the Paciorkowy reservoir) to $0,076 \mathrm{mg} \mathrm{NO}{ }_{2}^{-} \cdot \mathrm{dm}^{-3}$ (May 2015, point R2, the Rudziczka reservoir) - Figure 2. The values of this indicator qualify the investigated waters to quality class I.

An analysis of water quality shows that the determined concentrations of ammonia exceed the threshold values of water quality indicators for surface water bodies of class I $\left(0.412 \mathrm{mg} \mathrm{NH}{ }_{4}^{+} \cdot \mathrm{dm}^{-3}\right.$, May 2015, point St.P1, the Paciorkowy reservoir). The lowest content of nitrites $\left(0.023 \mathrm{mg} \mathrm{NH}_{4}{ }^{+} \cdot \mathrm{dm}^{-3}\right)$ was recorded in December 2014 at point St.R1, on the inflow to the Rudziczka reservoir.

The concentration of phosphates in water over the research period ranged from $0.003 \mathrm{mg} \mathrm{PO}_{4}{ }^{3-} \cdot \mathrm{dm}^{-3}$ (May 2015, point St.P1, the Paciorkowy reservoir) to $0.232 \mathrm{mg} \mathrm{PO}_{4}{ }^{3-} \cdot \mathrm{dm}^{-3}$ (December 2014, point St.R2, the Rudziczka reservoir). The highest level of this indicator has exceeded the threshold values of water quality indicators for surface water bodies of class I.

During the measurements the oxidation of water was very good in all the measurement locations. The content of oxygen ranged from $9.14 \mathrm{mg} \mathrm{O} \cdot \mathrm{dm}^{-3}$, in May 2015 in the Paciorkowy reservoir, to $18.9 \mathrm{mg} \mathrm{O}_{2} \cdot \mathrm{dm}^{-3}$, in May 2015 at point St.R2 - at the inflow to the Rudziczka reservoir (Fig. 2). The values of this indicator on all of the measurement points qualify the investigated waters as water quality class I. The reservoirs under analysis are not deep (average depth up to $0.85 \mathrm{~m}$ ), so there is no stratification. The table shows the results of water quality analyses for water from the research area. 
TABLE. The values of water quality indicators from the three small retention reservoirs in the forest district of Prudnik (own elaboration)

\begin{tabular}{|c|c|c|c|c|c|c|c|c|}
\hline \multirow[b]{2}{*}{ Sampling site } & \multirow[b]{2}{*}{ Date } & \multicolumn{7}{|c|}{ Pollution indicators } \\
\hline & & 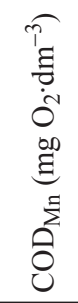 & 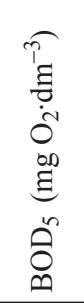 & 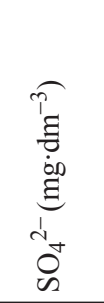 & 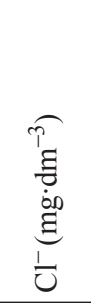 & 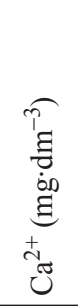 & 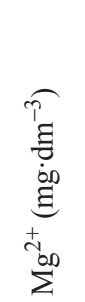 & 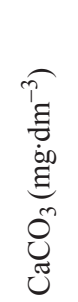 \\
\hline \multirow{2}{*}{ St.R1 } & XII.2014 & 3.71 & 2.23 & 49.38 & 52.4 & 3.19 & 0.8 & 3.99 \\
\hline & V.2015 & 4.9 & - & 53.49 & 66.15 & 2.34 & 1.8 & 4.14 \\
\hline \multirow{2}{*}{ St.R2 } & XII.2014 & 2.99 & 4.87 & 53.5 & 52.4 & 3.53 & 0.46 & 3.99 \\
\hline & V.2015 & 3.04 & - & 90.53 & 69.09 & 2.34 & 0.86 & 3.2 \\
\hline \multirow{2}{*}{ St.R3 } & XII.2014 & 4.54 & 2.23 & 49.38 & 53.5 & 3.28 & 0.71 & 3.99 \\
\hline & V.2015 & 3.43 & - & 45.26 & 56.11 & 2.54 & 0.85 & 3.39 \\
\hline \multirow{2}{*}{ St.N1 } & XII.2014 & 6.39 & 6.09 & 45.27 & 27.3 & 3.57 & 1.01 & 4.58 \\
\hline & V.2015 & 3.23 & - & 37.03 & 31.36 & 1.73 & 2.16 & 3.89 \\
\hline \multirow{2}{*}{ St.N2 } & XII.2014 & 3.3 & 1.43 & 49.38 & 32.2 & 2.24 & 0.99 & 3.23 \\
\hline & V.2015 & 4.51 & - & 41.15 & 33.56 & 2.11 & 0.89 & 3.0 \\
\hline \multirow{2}{*}{ St.P1 } & XII.2014 & 4.78 & 3.65 & 28.81 & 149.1 & 1.85 & 1.01 & 2.86 \\
\hline & V.2015 & 4.51 & - & 32.92 & 16.66 & 1.98 & 0.5 & 2.28 \\
\hline
\end{tabular}

The highest value of $\mathrm{BOD}_{5}(6.09$ $\mathrm{mg} \mathrm{O}_{2} \cdot \mathrm{dm}^{-3}$ ) was recorded in December 2014 in the Niemysłowice reservoir I - point St.N1 (Fig. 2). As a result, the values of this indicator exceeded the water quality threshold values for surface water bodies of class II. The highest value of $\mathrm{COD}_{\mathrm{Mn}}\left(6.39 \mathrm{mg} \mathrm{O}_{2} \cdot \mathrm{dm}^{-3}\right)$ was recorded also in December 2014 and also in the Niemysłowice reservoir I - point St.N1 (the table). The values of this indicator obtained at all of the measurement points qualify the investigated waters as water quality class I.

The highest concentration of sulphates from all of the measurement points was recorded in May 2015 at point St.R2 - the Rudziczka reservoir $\left(90.53 \mathrm{mg} \cdot \mathrm{dm}^{-3}\right)$.
The value of this indicator has exceeded the water quality threshold values for class II. On the other hand, the lowest concentration of sulphates was recorded in December $2014\left(28.81 \mathrm{mg} \cdot \mathrm{dm}^{-3}\right)$ in the Paciorkowy reservoir (the table).

The highest concentration of chlorides was recorded in May 2015 at point St.R2 - the Rudziczka reservoir $\left(69.09 \mathrm{mg} \cdot \mathrm{dm}^{-3}\right)$. The value of this indicator has exceeded the water quality threshold values for class II. On the other hand, the lowest concentration of chlorides was recorded also in May 2015 $\left(16.66 \mathrm{mg} \cdot \mathrm{dm}^{-3}\right)$ in the Paciorkowy reservoir (the table).

An analysis of water quality results shows that the levels of calcium do not 
exceed the water quality threshold values for surface water bodies of class I. The highest value of this indicator $\left(3.57 \mathrm{mg} \cdot \mathrm{dm}^{-3}\right)$ was observed in December 2014 and the lowest level of calcium $\left(1.73 \mathrm{mg} \cdot \mathrm{dm}^{-3}\right)$ was recorded in May 2015 at point St.R1 - inflow to the Rudziczka reservoir.

The content of magnesium in the waters of investigated small retention reservoirs during the research period ranged from $0.46 \mathrm{mg} \cdot \mathrm{dm}^{-3}$ (December 2014, point St.R2 - the Rudziczka reservoir) to $2.16 \mathrm{mg} \cdot \mathrm{dm}^{-3}$ (May 2015, point St.N1 - the Niemysłowice reservoir I) - the table. An analysis of water quality results over the research period shows that the values of this indicator qualify the waters to water quality class I.

The values of general hardness ranged from $2.28 \mathrm{mg} \mathrm{CaCO} \cdot \mathrm{dm}^{-3}$ (point St.P1, the Paciorkowy reservoir) to $4.58 \mathrm{mg} \mathrm{CaCO}_{3} \cdot \mathrm{dm}^{-3}$ (point St.N1 - the Niemysłowice reservoir I) - the table. An analysis of water quality results over the research period shows that the values of this indicator qualify the waters to water quality class I (Minister of Environment Regulation from 2014).

By analysing the seasonal fluctuations in the concentration of selected water quality indicators in the investigated water bodies, one may conclude that the concentrations in December 2014 were higher, compared to May 2015, for the following indicators: nitrates, phosphates, electrolytic conductivity, calcium and general hardness and lower for air temperature, reaction, nitrites, ammonia and dissolved oxygen.

As shown by the measurements, the surface waters in the Paciorkowy reservoir (St.P1) were of the lowest quality whereas those in the Rudziczka reservoir (St.R2) were of the highest quality.

The reservoirs built in the forest district of Prudnik are prone to gradual degradation, which is mainly because of their modest morphometric parameters (small surface area and volume). The quality of water in reservoirs depends on the quality of water in the watercourses that feed into them (Wiatkowski 2015). Moreover, the method of use of the catchment area of the small reservoirs is fundamental for the quality of water in these reservoirs (Bedla and Misztal 2014). It should be noted that the content of individual substances being investigated are within the lower limits given by Bedla and Misztal (2014) for the measurements carried out in a small drainless reservoir Bonar located in a forest catchment (forest cover $56.1 \%$ and permanent pastures $24.9 \%$ ) in the valley of the Rudno stream (left tributary of the Wisła, district of Kraków). The authors of this study found out that the maximum concentration of $\mathrm{Cl}^{-}$in the reservoir located within a settlement-agricultural catchment was $235.5 \mathrm{mg} \cdot \mathrm{dm}^{-3}$, whereas the same parameter for a water body located in an agricultural-forested area was over ten times lower $\left(22.2 \mathrm{mg} \cdot \mathrm{dm}^{-3}\right)$. In the case of the reservoir in a settlement-agricultural catchment the recorded concentrations of phosphates were higher due to the unresolved water and sewage management in this catchment. Based on the research carried out in the Sudety Foothills, Paluch (1994) noted that the amount of phosphorus discharged from the catchments used for agriculture is higher than that which is observed in forested catchments. As regards the nitrogen compounds, the concentration of 
nitrate nitrogen discharged from forested catchments was slightly higher than in agricultural catchments (Paluch 1994). Interesting results for small mid-field reservoirs, rural ponds and mid-forest reservoirs located in the Olsztyńskie lake district were presented by Skwierawski (2010) based on the research by Koc et al. (2001). These results show that the investigated mid-forest reservoir had low concentrations of the main indicators decisive for water quality, e.g. nitrates $\left(0.04 \mathrm{mg} \mathrm{N}-\mathrm{NO}_{3}{ }^{-} \cdot \mathrm{dm}^{-3}\right)$, ammonia $\left(0.89 \mathrm{mg} \mathrm{N}-\mathrm{NH}_{4}{ }^{+} \cdot \mathrm{dm}^{-3}\right)$, phosphates $\left(0.10 \mathrm{mg} \mathrm{P}_{-} \mathrm{PO}_{4}{ }^{3-} \cdot \mathrm{dm}^{-3}\right)$, chlorides $\left(10.5 \mathrm{mg} \cdot \mathrm{dm}^{-3}\right)$ and values of electrolytic conductivity $(165 \mu \mathrm{S} / \mathrm{cm})$. The results obtained in the forest district of Prudnik are close to those for the mid-forest reservoir “Olsztyński” (Skwierawski 2010). Based on the measurements performed in the reservoirs of the Olsztyńskie lake district it has been concluded that compared to mid-forest reservoirs the midfield and rural ponds investigated in the Olsztyńskie lake district usually displayed higher values of electrolytic conductivity, $\mathrm{N}-\mathrm{NO}_{3}{ }^{-}, \mathrm{P}-\mathrm{PO}_{4}{ }^{3-}$, chlorides and potassium. In a comparison between the mid-forest reservoir and rural ponds, the mid-field structures displayed higher concentrations of ammonia (Skwierawski 2010).

The investigated waters from the small retention reservoirs located in the forest district of Prudnik, were not classified as eutrophic because the admissible level of nitrates $\left(10 \mathrm{mg} \mathrm{NO}{ }_{3}^{-} \cdot \mathrm{dm}^{-3}\right)$, set in the Minister of Environment Regulation from 23 December 2002 was not exceeded.

Testing of water from the small retention reservoirs in the forest district of Prudnik shows that indicators such as reaction, dissolved oxygen and ammonia nitrogen meet the requirements for inland water habitats of salmonids and cyprinids in natural conditions (Minister of Environment Regulation from 4 October 2002). As regards the temperature of water, it meets the requirements for inland water habitats of both cyprinids and salmonids in all the reservoirs except for the Rudziczka reservoir (point R2), where the temperature exceeds the value required for salmonids.

The fish living conditions are most deteriorated by the level of $\mathrm{BOD}_{5}$, which exceeds the required value of $3 \mathrm{mg}$ $\mathrm{O}_{2} \cdot \mathrm{dm}^{-3}$ for salmonids in the Rudziczka reservoir (point R2) and the Paciorkowy reservoir (point P1). In the Niemysłowice reservoir I (point N1) the same indicator exceeds $6 \mathrm{mg} \mathrm{O}_{2} \cdot \mathrm{dm}^{-3}$ - the value required for cyprinids.

The living conditions for fish are worsened most by the nitrites, which exceed $0.01 \mathrm{mg} \mathrm{NO}{ }_{2}^{-} \cdot \mathrm{dm}^{-3}$, i.e. the level required in the Minister of Environment Regulation from 4 October 2002 for salmonids at all the points except for St.P1 - the Paciorkowy reservoir and also exceeded $0.03 \mathrm{mg} \mathrm{NO}_{2}^{-} \cdot \mathrm{dm}^{-3}$, i.e. the level required for cyprinids in May 2015 in the Rudziczka reservoir - points St.R1, St.R2 and St.R3.

The importance of the quality of underground and surface waters in forests is underlined by Tyszka (2004). The author states that although the chemical content of these waters does not necessarily need to meet the applicable standards for water for public services (provided that the waters are not used for drinking or household purposes), however, it may not contain any substances 
that are toxic for the forest ecosystem, avifauna, forest animals, green herbs and most importantly trees (Tyszka 2004). With the increase of pollution in the environment the role of forests in shaping the quality of water increases (Pierzgalski 2012). Such research is in line with the recommendations of specialists in water management in forested areas, including those of Pierzgalski (2012), who claims that it is necessary to implement a system for the monitoring of hydrological phenomena in forests that would be connected with the national surface and ground water monitoring system. The monitoring that provides information on the qualitative and quantitative changes in water resources in forests is a basic tool that indicates the condition, threats and actions required to limit any unfavourable trends in this respect.

As mentioned by Frydel (2006), the reservoirs recreated in the forest district of Kaliska change the surrounding environment. Water and wetland organisms have been observed in and around the recreated reservoirs already after one year from their recreation and after several years some amphibians and insects returned. Some fish species, previously present in these waters, were reintroduced (Frydel 2006). A similar situation occurs in small retention reservoirs in the forest district of Prudnik. Grass snakes, swans and great reed warbler appeared. As stated by Mioduszewski (2016), it is difficult to overestimate the significance of these small reservoirs for creating conditions for biodiversity. They can be valuable ecosystems with rich flora and fauna (Mioduszewski 2016) and implementation of such reservoirs adds variety to the landscape and increases biodiver- sity (Bielecka 2006). As specified in the technical documentation of the reservoir (Nadleśnictwo Prudnik 2010), after commissioning the investments will not pose any threats to natural environment. The accomplishment of tasks expected of small retention reservoirs should be evaluated based on efficiency criteria, such as e.g. curbing of flood-related damages or improvement of water cleanness (Wiatkowski 2014).

\section{CONCLUSIONS}

The main function of the reservoirs discussed in this paper is retention of water (the Rudziczka, Niemysłowice I and Paciorkowy reservoirs), flood protection (Rudziczka, Niemysłowice I and Paciorkowy), fire protection (Rudziczka, Niemysłowice I and Paciorkowy), recreation (Paciorkowy and Niemysłowice I) and ecology (Niemysłowice I and $\mathrm{Pa}-$ ciorkowy).

An increase of water resources in forests and slowing down of the surface runoff, thanks to the construction of structures such as the reservoirs discussed here, is very important for the development of forests and the areas located below (e.g. the chain reservoirs). Where possible old small retention reservoirs should be regenerated and new ones should be built.

The measurements of water quality performed in the small retention reservoirs located in the forest district of Prudnik show that:

- in terms of electrolytic conductivity, nitrates, nitrites, dissolved oxygen $\mathrm{COD}_{\mathrm{Mn}}$, calcium, magnesium and general hardness, the reservoirs under study fall into water quality class I; 
- in terms of the temperature of water (the Rudziczka reservoir), ammonia and phosphates, the reservoirs under study fall into water quality class II;

- in terms of water reaction, $\mathrm{BOD}_{5}$, sulphates and chlorides the threshold levels of water quality indicators for surface water bodies of class II have been exceeded (Minister of Environment Regulation from 2014).

Because of the low content of nitrates, the water from the reservoirs was deemed not eutrophic.

The analyses carried out confirm their suitability as habitat for salmonids and cyprinids in terms of water reaction, dissolved oxygen and ammonia nitrogen, as well as in terms of the temperature of water in all the reservoirs except for the Rudziczka reservoir (point R2), where the temperature exceeds the value required for salmonids. The fish living conditions are most deteriorated by the level of $\mathrm{BOD}_{5}$.

The analysis of seasonal fluctuations of water quality indicators in the investigated water bodies shows that in winter the indicators were higher for nitrates, phosphates, electrolytic conductivity, calcium and general hardness and lower for the temperature of water, reaction, nitrites, ammonia and dissolved oxygen.

As shown by the measurements, the surface waters in the Paciorkowy reservoir (St.P1) were of the lowest quality whereas those in the Rudziczka reservoir (St.R2) were of the highest quality.

The research initiated in the forest district of Prudnik provides preliminary information on the quality of water in in small retention reservoirs. In order to obtain more accurate data, this research needs to continue. Regular water qual- ity testing in these reservoirs is required. These actions will help with taking correct economical decisions on issues related to the use of water retained in the reservoir and its protection by its administrator - the Regional State Forest Directorate in Katowice.

\section{REFERENCES}

BEDLA D., MISZTALA. 2014: Changeability of Chemistry of Small Water Reservoirs with Diversified Use Structure of the Adjoining Areas. Rocz. Ochr. Srod. 16: 421-439. Retrieved from http://towarzystwo.ros.edu.pl/images/roczni$\mathrm{ki} / 2014 / \mathrm{pp} \_2014 \_01 \_27 . p d f$.

BIELECKA J. 2006: Oczka wodne. [in:] W. Mioduszewski (Ed.). Woda w krajobrazie rolniczym. Wydawnictwo Instytutu Melioracji i Użytków Zielonych, Falenty, 89-107.

CIEPIELOWSKI A. 2001: Kształtowanie retencji wodnej w lasach. Wydawnictwo Instytutu Melioracji i Użytków Zielonych, Falenty, Zeszyt 146: 20.

CIEPIELOWSKI A. 2004: Zasady gospodarowania wodą w lasach. Postępy i Techniki w Leśnictwie 86: 25-31.

FRYDEL K. 2006: Mała retencja na obszarze nadleśnictwa. Biblioteczka Leśniczego 233: 16.

KOC J., CYMES I., SKWIERAWSKI A., SZYPEREK U. 2001: Znaczenie ochrony małych zbiorników wodnych w krajobrazie rolniczym. ZPPNR 476: 397-407.

JANUSZ E., JĘDRYKA S., KOPEĆ D., MILER A.T. 2011: Woda dla lasu - las dla wody, na przykładzie Nadleśnictwa Kolumna. Infrastruktura i Ekologia Terenów Wiejskich 1: 275-288. Retrieved from http://www.infraeco.pl/en/art/a_15893. htm.

LIBERACKI D., SZAFRAŃSKI Cz. 2008: Contents of Biogenic Components in Surface Waters of Small Catchments in the Zielonka Forest. Rocz. Ochr. Środ. 
10: 181-192. Retrieved from http:// ros.edu.pl/images/roczniki/archive/pp 2008_012.pdf.

LIBERACKI D., SZAFRAŃSKI Cz., STASIK R., KORYTOWSKI M. 2008: Bilans wodny małej zlewni leśnej. ZPPNR 528: 251-257. Retrieved from http://www1. up.poznan.pl/imksig/wp-content/uploads/2014/08/Publikacje2008/7-2008.pdf.

MAŁEK S., GAWĘDA T. 2006: Charakterystyka chemiczna źródeł Potoku Dupniańskiego w Beskidzie Śląskim. Sylwan 3: 39-46. Retrieved from http://wl.ur. krakow.pl/zasoby/3/Malek\%20Gaweda2006b.pdf.

MILER A.T. 2009: Stan obecny małej retencji wodnej oraz perspektywy jej rozbudowy na przykładowych terenach leśnych w Wielkopolsce. Infrastruktura i Ekologia Terenów Wiejskich 4: 231-237. Retrieved from http://www.infraeco.pl/en/art/ a 15503.htm.

MILER A.T. 2015: Mała retencja wodna w polskich lasach nizinnych. Infrastruktura i Ekologia Terenów Wiejskich 4 (1): 979-992. DOI: http://dx.medra. org/10.14597/infraeco.2015.4.1.078

MIODUSZEWSKI W. 2004: Rola małej retencji w kształtowaniu i ochronie zasobów wodnych. Zesz. Nauk. AR we Wrocławiu, Inż. Środ. 13, 502: 293-305.

MIODUSZEWSKI W. 2008: Mała retencja w lasach elementem kształtowania i ochrony zasobów wodnych. Studia i Materiały Centrum Edukacji Przyrodniczo-Leśnej 10, 2 (18): 33-48.

MIODUSZEWSKI W. 2016: Innowacyjne metody tworzenia małej retencji. In Innowacyjne metody gospodarowania zasobami wody $\mathrm{w}$ rolnictwie. Wydawnictwo Centrum Doradztwa Rolniczego w Brwinowie, Brwinów: 11-26. Retrieved from https://www. researchgate.net/profile/Grzegorz_Zurek2/publication/319167657_INNOWACYJNE_METODY_GOSPODAROWANIA ZASOBAMI WODY W_ROLNICTWIE_Praca_zbiorowa_pod_red_W Wembek_J $_{-}^{-}$
Kus M Wiatkowski G Zurek/ links/5996 2 2fda6fdcc35 $\bar{c} 6 \mathrm{cb} 85 \mathrm{~d} 6 / \mathrm{IN}$ NOWACYJNE-METODY-GOSPODAROWANIA-ZASOBAMI-WODY-W-ROLNICTWIE-Praca-zbiorowa-podred-W-Dembek-J-Kus-M-WiatkowskiG-Zurek.pdf.

MOSIEJ J., BUS A. 2015: New challenges in rural water management in Poland. Proceedings of the International Scientific Conference: Rural Development 2015. DOI: 10.15544/RD.2015.078

Nadleśnictwo Prudnik 2010a: Program małej retencji, ochrony i regeneracji systemów mokradłowych na terenie Nadleśnictwa Prudnik. Prudnik.

Nadleśnictwo Prudnik 2010b: Wniosek o decyzję lokalizacji inwestycji celu publicznego - zbiornik Rudziczka. PGL Lasy Państwowe, Prudnik. Retrieved from http://www.prudnik.pl/download/attachment/28735/zbiornik-rudziczka-uzupelwniosku.pdf.

Nadleśnictwo Prudnik 2014: Program ochrony przyrody dla Nadleśnictwa Prudnik. Retrieved from http://bip.lasy.gov.pl/pl/bip/ px_dg rdlp_katowice $\sim$ nadl_prudnik program_ochrony_przyrody.pdf.

NIKEL D: Kształtowanie małej retencji wodnej w Nadleśnictwie Prudnik. Praca dyplomowa, Uniwersytet Opolski, KOPZ, Opole [manuskrypt].

OSTROWSKI K. 2011: Gospodarowanie zasobami wodnymi na terenach wiejskich w Polsce i w Bawarii. In: J. Pijanowski (Ed.). Podniesienie jakości kształcenia akademickiego w zakresie geodezyjnego urządzania obszarów wiejskich w oparciu o doświadczenia praktyki i szkolnictwa wyższego Bawarii. Wydawnictwo Uniwersytetu Rolniczego w Krakowie, Kraków. Retrieved from http://matrix. ur.krakow.pl/ isig/nowy/artykuly/04_Gospodarowanie_zasobami_wodnymi.pdf.

PALUCH J. 1994: Porównanie jakości wód odpływających z sąsiadujących ze sobą zlewni rolniczej i zalesionej $\mathrm{w}$ Kotlinie Marciszowskiej w latach 1987-1989. Prace IBL 21/1, B: 129-143. 
PIERZGALSKI E. 2008. Relacje między lasem a wodą - przegląd problemów. Studia i Materiały Centrum Edukacji Przyrodniczo-Leśnej 10, 2 (18): 13-23.

PIERZGALSKI E. 2012: Gospodarowanie wodą w obszarach leśnych. Wiadomości Melioracyjne i Łąkarskie 55 (1): 7-9. Retrieved from http://wmil.sitwm.pl/ templates/wmil/images/wydania/2012/12012.pdf.

Rozporzadzenie Ministra Środowiska z dnia 23 grudnia 2002 r. w sprawie kryteriów wyznaczania wód wrażliwych na zanieczyszczenie związkami azotu ze źródeł rolniczych. Dz.U. 2002 nr 241, poz. 2093.

Rozporządzenie Ministra Środowiska z dnia 4 października 2002 r. w sprawie wymagań, jakim powinny odpowiadać wody śródlądowe będące środowiskiem życia ryb w warunkach naturalnych. Dz.U. $2002 \mathrm{Nr}$ 176, poz. 1455.

Rozporządzenie Ministra Środowiska z dnia z dnia 22 października 2014 r. w sprawie sposobu klasyfikacji stanu jednolitych części wód powierzchniowych oraz środowiskowych norm jakości dla substancji priorytetowych. Dz.U. 2014, poz. 1482.

SKWIERAWSKI A. 2010: Funkcjonowanie małych zbiorników wodnych w różnych typach krajobrazu. In: J. Koc (Ed.) Ochrona zasobów i jakości wody w krajobrazie wiejskim. Wydawnictwo Uniwersytetu Warmińsko-Mazurskiego Olsztyn: 175-195. Retrieved from https://www.researchgate.net/ profile/Andrzej_Skwierawski/publication/253649548_Funkcjonowanie malych_zbiornikow_wodnych_ w_roznych_typach_k̄ rajobrazu/ links/00b7d $\overline{5} 1 \mathrm{fa} 0886 \overline{5} 72 \mathrm{c} 9000000 /$ Funkcjonowanie-malych-zbiornikowwodnych-w-roznych-typach-krajobrazu. pdf.

STASIK R., SZAFRAŃSKI Cz., KORYTOWSKI M., LIBERACKI D. 2011: Kształtowanie się zasobów wodnych w małych zlewniach leśnych na obszarze Wielkopolski. Rocz. Ochr. Środ. 13:
1679-1696. Retrieved from http://ros. edu.pl/images/roczniki/archive/pp 2011_107.pdf.

SZCZYKOWSKA J., SIEMIENIUK A., WIATER J. 2017: Trophic state of small retention reservoirs in Podlasie Voivodeship. J. Ecol. Eng. 18 (5): 153-160. DOI: 10.12911/22998993/74627

TYSZKA J. 2004: Przyczyny zakłóceń warunków wodnych i metody łagodzenia ich skutków w ekosystemach leśnych. Postępy Techniki w Leśnictwie 86: 49-53.

TYSZKA J. 2009: Estimation and economic valuation of the forest retention capacities. J. Water Land Dev. 13a: 149-159. DOI: $10.2478 / \mathrm{v} 10025-010-0025-6$

WIATKOWSKI M. 2014: Charakterystyka wybranych działań z zakresu małej retencji w lasach województwa opolskiego. In: T. Kałuża, P. Strzeliński (Eds.). Problemy gospodarowania wodą na terenach leśnych, zurbanizowanych i niezurbanizowanych. Bogucki Wydawnictwo Naukowe, Poznań: 60-78.

WIATKOWSKI M. 2015: Problemy gospodarki wodnej zbiornika Młyny na rzece Julianpolka. Acta Sci. Pol. Formatio Circumiectus 14 (3): 191-203. DOI: http://dx.doi.org/10.15576/ASP. FC/2015.14.3.191

WIATKOWSKI M. 2016: Przegląd wybranych problemów gospodarki wodnej na obszarze zlewni rzek. In: Innowacyjne metody gospodarowania zasobami wody w rolnictwie. Wydawnictwo Centrum Doradztwa Rolniczego w Brwinowie Brwinów: 27-59.

Streszczenie: Ksztaltowanie sie jakości wody $w$ leśnych zbiornikach wodnych $w$ pierwszym okresie ich eksploatacji na przyktadzie wybranych obiektów w potudniowej Polsce. W pracy przedstawiono analize jakości wód $\mathrm{z}$ terenów trzech nowopowstałych zbiorników małej retencji leśnej (Rudziczka, Niemysłowice I, zbiornik Paciorkowy) zlokalizowanych na terenie Nadleśnictwa Prudnik, w województwie opolskim (południowa Polska). Głównymi funkcjami zbiorników są retencja wody, ochrona przeciw- 
powodziowa i przeciwpożarowa, funkcje rekreacyjna i ekologiczna. W pracy przedstawiono wyniki badań wykonanych w grudniu 2014 i w maju 2015 roku. Oceny jakości wód dokonano zgodnie z obowiązującymi przepisami w sprawie oceny jakości wód. Ponadto przedstawiono ocenę eutrofizacji wód oraz walory użytkowe wody zbiorników (analiza przydatności badanej wody do bytowania ryb). Badania wykazały, że badane wody ze względu na wartości przewodności elektrolitycznej, zawartości azotanów, azotynów, tlenu rozpuszczonego, $\mathrm{ChZT}_{\mathrm{Mn}}$, wapnia, magnezu i twardości ogólnej klasyfikowały się do klasy I jakości; pod względem wartości temperatury (zbiornik Rudziczka), zawartości amoniaku i fosforanów klasyfikowały się do klasy II. Odczyn, $\mathrm{BZT}_{5}$ oraz zawartość siarczanów i chlorków przekroczyły wartości graniczne dla klasy II. Stwierdzono także, że badane wody nie są eutroficzne. Z wykorzystaniem wskaźników, takich jak: odczyn, tlen rozpuszczony i azot amonowy oraz temperatura, ustalono, że wody we wszystkich obiektach oprócz zbiornika Rudziczka spełniały wymagania jakościowe do bytowania ryb łososiowatych i karpiowatych. Najbardziej niekorzystne warunki do bytowania ryb powoduje podwyższona zawartość $\mathrm{BZT}_{5}$ oraz azotynów $\mathrm{w}$ wodach zbiornika Rudziczka i zbiornika Paciorkowego. Analiza sezonowych wahań koncentracji wskaźników jakości wody w badanych akwenach wykazała, że w okresie zimowym największe wartości zarejestrowano w odniesieniu do azotanów, fosforanów, wapnia, przewodności elektrolitycznej oraz twardości ogólnej, a najmniejsze temperatury, odczynu, azotynów, amoniaku i tlenu rozpuszczonego. Najgorszą jakością charakteryzowały się wody w zbiorniku Paciorkowym, a najlepszą wody powierzchniowe zbiornika Rudziczka. Badania rozpoczęte na terenie zbiorników małej retencji leśnej dostarczaja wstepnych informacji na temat jakości wód i znaczenia badanych zbiorników w tworzeniu warunków dla zwiększenia retencji.

Słowa kluczowe: małe zbiorniki wodne, zlewnia leśna, jakość wody, użytkowanie wody, Nadleśnictwo Prudnik

$M S$ received 10.02.2018

MS accepted 26.03.2018

\section{Authors' address:}

Mirosław Wiatkowski

Instytut Inżynierii Środowiska

Wydział Inżynierii Środowiska i Geodezji

Uniwersytet Przyrodniczy we Wrocławiu

pl. Grunwaldzki 24, 50-363 Wrocław

Poland

e-mail: miroslaw.wiatkowski@upwr.edu.pl 